\title{
間葉系幹細胞からの血小板創製技術の医療応用研究
}

\author{
松原由美子*

\section{Manufacturing of platelets from human adipose tissue-derived mesenchymal stem cell line for future clinical application}

\author{
Yumiko MATSUBARA
}

\begin{abstract}
要約 : Platelets are released from mature megakaryocytes (MKs) and are used for therapeutic application, especially platelet transfusion. Platelet concentrates used for platelet transfusions are currently supplied by volunteer donors. Due to their short shelf life (4 days in Japan and 5 days in US), however, donor-dependent platelet concentrates are associated with practical problems, such as the limited supply and the risk of infection. Thus, new strategies for manufacturing MKs and subsequently platelets from a donor-independent source are urgently needed. Mesenchymal stem cells (MSCs) are known to be non-hematopoietic multipotent progenitor-cells. We found that MSCs/stromal cells differentiated into MKs and platelets. The clinical needs for platelet transfusions are increasing. Adipose tissue-derived MSCs/stromal cells are an attractive candidate cell source because inducing these cells into MK-lineages requires no gene transfer and only endogenous transcription factors containing p45NF-E2/Maf, an MK-inducing factor and endogenous thrombopoietin, a primary cytokine that drives MK lineages. Thus, we developed a manufacturing system for platelets from donorindependent cell source, human adipose-derived mesenchymal stromal/stem cell line (ASCL). ASCL satisfied the minimal criteria for defining MSC by The International Society for Cellular Therapy. ASCL-derived platelets (ASCLPLT) were obtained with a peak at Day 12 of culture using MK lineage induction media. We observed that CD42bpositive cells expressed a MSC marker CD90 in relation to cell adhesion. The pattern of in vivo kinetics after being infused into irradiated immunodeficient NSG mice was similar to that of platelet concentrates. ASCL-PLT has characterization observed in other platelet populations and might have additional function as MSC. The present protocol is a simple method that requires no feeder cells, further enhancing the clinical application of our approach.
\end{abstract}

Key words: Platelets, Megakaryocytes, Mesenchymal stem cells, Thrombopoietin

\section{1. はじめに}

血小板は成熟した巨核球から放出され，生理的止 血, 病的血栓, 組織修復など多様な機能を有する。 血小板の産生機構は未だ不明点は多いが, in vitroで の血小板分化誘導研究により知見が蓄積されてい る. その血小板分化誘導研究の応用のひとつとして 医療応用目的の血小板作製研究が注目されている。

\footnotetext{
*責任者連絡先：

慶應義塾大学医学部臨床研究推進センター臨床検査医学

干 160-0082 東京都新宿区信濃町 35

Tel: 03-5315-4366

E-mail: yumikoma@keio.jp
}

同様研究の世界動向としては輸血製剂への展開を目 的とした血小板作製研究が多い. 血小板は止血作用 を有する他類なき細胞であり，血小板輸血製剤とし て血液疾患や抗がん剂治療時などにおける血小板減 少に用いられる。血小板輸血製剂は $100 \%$ 献血に依 存, 保存期間が僅か 4 日間, 高齢化社会に伴う需要 増加と献血者減少という問題を有している。 また感 染のリスク懸念が残る。そこで血小板を計画的に大 量作製し医療に応用する試みとして，そのスタート 細胞に幹細胞等を用いた血小板分化誘導が用いられ ている．幹細胞（定義：自己複製能と分化能を持つ） は, ES 細胞や iPS 細胞のような多能性幹細胞と造血 幹細胞や間葉系幹細胞など特定の組織・細胞へ分化 
できる組織幹細胞に大別される，血小板作製が報告 されている幹細胞は, ES 細胞, iPS 細胞, 造血幹細 胞, 間葉系幹細胞/間質細胞である. また, 転写因子 NF-E2 導入の皮膚線維芽細胞から血小板作製が報告 されている ${ }^{1-3)}$. これらの中で筆者らのグループが見 出したスタート細胞 (間葉系幹細胞/間質細胞, 転写 因子 NF-E2 導入の皮膚線維芽細胞）からの血小板産 生, 皮下脂肪から得た間葉系幹細胞からの血小板の 医療応用に向けた取り組みについて概説したい.

\section{2. 間葉系幹細胞}

間葉系幹細胞の定義（国際細胞治療学会：The International Society for Cellular Therapyによる）は, (1)in vitro で接着細胞として増殖すること, (2)CD73・ CD90・CD105 陽性であり，かつ CD45・CD34・ $\mathrm{CD} 14 \cdot \mathrm{CD} 11 \mathrm{~b} \cdot \mathrm{CD} 79 \mathrm{a} \cdot \mathrm{CD} 19$ およびヒト白血球抗 原 class II 陰性であること, (3)骨芽細胞, 脂肪細胞, 軟骨細胞への分化能を有すること, とされてい $る^{4,5)}$. 間葉系幹細胞は, 骨髄, 脂肪, 歯髄, 胎盤な どに存在する。これらの細胞はどれも上記の間葉系 幹細胞の定義を満たすが, その増殖能や分化能に関 して，多様性があることが知られている。間葉系幹 細胞の生体内での役割の大きな特徴は, 免疫反応調 節, 創傷治癒において重要な役割を持つことである. その機序は多岐にわたるが, いくつか例を上げると, 好中球のアポトーシス抑制, マクロファージの創部 への遊走移動, リンパ球へ作用し炎症性サイトカイ ンの抑制・抗炎症性サイトカインの合成促進 · regulatory $\mathrm{T}$ 細胞の割合増加などの報告がある. 間葉 系幹細胞は, そのほかにも, 細胞外マトリックスや 細胞接着因子, 成長因子などの創傷治癒を促進する 様々な因子の細胞膜発現や分泌が知られている。間 葉系幹細胞は, その免疫調節能, 創傷治癒促進能, 多彩な細胞への分化能などにより, 創傷治癒や再生 医療などの分野で注目を集め, 医療応用に向けた 様々な臨床試験が行われている. 既に薬事承認を受 けている製品も存在する. 免疫調節能に着目した使 用法として, 国内では同種骨髄由来間葉系幹細胞 (テ ムセル ${ }^{\circledR} \mathrm{HS}$ 注）として造血幹細胞移植後の急性移植 片対宿主病に対しての再生医療等製品として承認さ
れており, 同種骨髄由来間葉系幹細胞のヒト投与へ の安全性・有効性が確認されている. 創傷治癒関連 では, 糖尿病性下肢潰瘍に対する自家骨髄由来 CD 90 陽性細胞投与の臨床試験や, 未発表だが自家脂肪組 織由来間葉系幹細胞の潰瘍に対する投与試験などが 計画されている ${ }^{6,7)}$. 医療応用に拈いては, 採取して きた細胞を in vitro で大量に拡大培養する必要が あり,この工程は現在も最適化開発が必要とされて いる.

筆者の研究グループは, 骨髄あるいは皮下脂肪に 存在する間葉系幹細胞/間質細胞が巨核球・血小板に 分化しうることを見出し，そのメカニズムの解明・ 血小板分化のスタート細胞が間葉系幹細胞であるこ とを報告した。

\section{3. マウスおよびヒトの間葉系幹細胞/間質細胞か らの巨核球・血小板産生}

2000 年代, 多能性幹細胞 (iPS 細胞や ES 細胞) か らの巨核球・血小板産生は, 主に feeder 細胞と幹細 胞を組換えトロンボポエチン（TPO）存在下で培養 して行われていた. 筆者の研究グループも同様であっ た，その実験において, negative control として feeder 細胞 (OP9 細胞 : マウス骨髄脂肪前駆細胞株/間葉系 幹細胞株）のみを用いて血小板産生の実験を行って いたが, その場合でも巨核球・血小板への分化を認 めた ${ }^{8)}$. 最初は, 細胞が巨核球同様の形態, フロー サイトメトリー解析における CD42b, CD41 陽性細 胞の確認を認めた。この知見はヒト皮下脂肪由来間 葉系幹細胞/間質細胞においても認められた ${ }^{9)}$ 。これ ら観察結果を端緒にメカニズム解明研究を行った。 メカニズム解明研究は, サイトカインや転写因子に 着目して進めていった (後述).

\section{4. 巨核球・血小板への細胞分化決定因子として 転写因子 p45NF-E2 の同定 : 線維芽細胞から巨 核球・血小板のダイレクトリプログラミング}

血球分化を司る重要因子は, サイトカインと転写 因子である.巨核球分化に必須のサイトカインは TPO が同定されているが，転写因子は不明であった 
ため, 先ずは巨核球・血小板分化に重要な転写因子 の同定を行うことに着手した，手がかりとして，こ れまでの知見 (脂肪前駆細胞株 3T3-L1 は巨核球・血 小板に分化するが，3T3-L1の親細胞である 3T3 線維 芽細胞株は巨核球・血小板に分化しない） ${ }^{10)}$ を活用 して, これら細胞の遺伝子発現プロファイルを詳細 に比較した. 3T3-L1に発現し，3T3に発現していな い因子に着目し解析した結果, CEBP alpha と p45NF$\mathrm{E} 2$ が細胞間の発現量に大きな差をもって認められ た. CEBP alpha は脂肪分化に重要な転写因子である ことから, p45NF-E2 が巨核球・血小板分化に関連す る因子の候補となった。 ヒト，マウスそれぞれの線 維芽細胞に p45NF-E2 とその結合因子 Mafを遺伝子 導入し, 分化誘導培地 (造血幹細胞からの巨核球分 化誘導培地と同じ培地）で培養した。遺伝子導入細 胞の詳細な解析 (表面抗原, DNA ploidy, 電子顕微 鏡観察, 免疫染色, Filoposia, Lamellipodia, 巨核球 輸注による血小板体内放出, 機能解析など）により, 巨核球・血小板への分化が確認された. 上記分化誘 導培地で培養した発現ベクターのみを導入した線維 芽細胞や導入なしの線維芽細胞では巨核球・血小板 の分化は認められなかった。したがって，巨核球・ 血小板への細胞分化決定因子として, 転写因子 p45NF-E2 が同定された ${ }^{11)}$.

\section{5. 脂肪由来間葉系幹細胞/間質細胞は巨核球・血 小板への細胞分化決定因子 p45NF-E2 を内在}

前述のダイレクトリプログラミング研究成果は, 細胞の p45NF-E2 内在は巨核球・血小板に分化しう る可能性があることを示唆していた。 そこで間葉系 幹細胞/間質細胞の遺伝子発現を ES 細胞, Bone marrow mononuclear cells とともに行った. その結果, p45NF-E2 発現は Bone marrow mononuclear cells と間 葉系幹細胞/間質細胞に認められ, 巨核球・血小板分 化に伴って発現量が増加した。間葉系幹細胞/間質細 胞への p45NF-E2 強制発現は, 巨核球の産生増加を 示した。これら結果により, 間葉系幹細胞/間質細胞 が巨核球・血小板への分化決定因子である p45NF-E2 を内在し, その発現量増加を伴って巨核球・血小板 に分化するメカニズムが示唆された。 さらに間葉系
幹細胞/間質細胞は, GATA2，RUNX1，Fli，FOG な ど巨核球・血小板分化に重要な転写因子を内在して いることを見出した ${ }^{8)}$. 一方, ES 細胞に発現してい る多能性関連遺伝子の発現は間葉系幹細胞/間質細 胞では認めなかった。

\section{6. 脂肪由来間葉系幹細胞/間質細胞はトランス フェリン刺激時, 内在 TPO が c-MPL を介して 巨核球・血小板に分化}

次に, サイトカインに着目したメカニズム解明研 究を行なった. 脂肪由来間葉系幹細胞/間質細胞の遺 伝子解析を重ねていた際, 脂肪由来間葉系幹細胞/間 質細胞は巨核球・血小板分化に重要な転写因子のみ ならず, TPO 遺伝子の発現も認めた. TPOの産生箇 所は肝臓であることが知られている。したがって, 造血幹細胞や多能性幹細胞から巨核球・血小板の分 化誘導を行う際には組換え TPO の添加が必要であ る. しかし, 脂肪由来間葉系幹細胞/間質細胞は TPO 遺伝子を内在していた。筆者の研究グループでの Questionは, 脂肪由来間葉系幹細胞/間質細胞で観察 される TPO 遺伝子は機能を有する TPO として細胞 外に分泌され，巨核球・血小板への分化を促すか? であった，TPO遺伝子は，巨核球・血小板分化にし たがって発現増加を示した. さらに TPO 分泌が培養 上清にELISA解析により認められた。この分泌 TPO を含有する培地を用いて造血幹細胞を培養した結 果, 巨核球・血小板分化を認めた。脂肪由来間葉系 幹細胞/間質細胞は, 巨核球分化誘導に伴い内在 TPO を分泌し TPO 受容体である c-MPLを介して巨核球・ 血小板へと分化する. その内在 TPO はトランスフェ リン添加刺激によりトランスフェリン受容体 CD71 を介した刺激により細胞外一分泌されることを見出 した ${ }^{12)}$ 。つまり間葉系幹細胞/間質細胞が巨核球・血 小板分化のスイッチ ON となるのはトランスフェリ ン添加刺激によることが解明された（図1)。これら 結果により, 間葉系幹細胞/間質細胞が巨核球・血小 板への分化重要サイトカイン TPO を内在し, その細 胞外分泌, 受容体刺激を伴って巨核球 - 血小板に分 化するメカニズムが示唆された。 


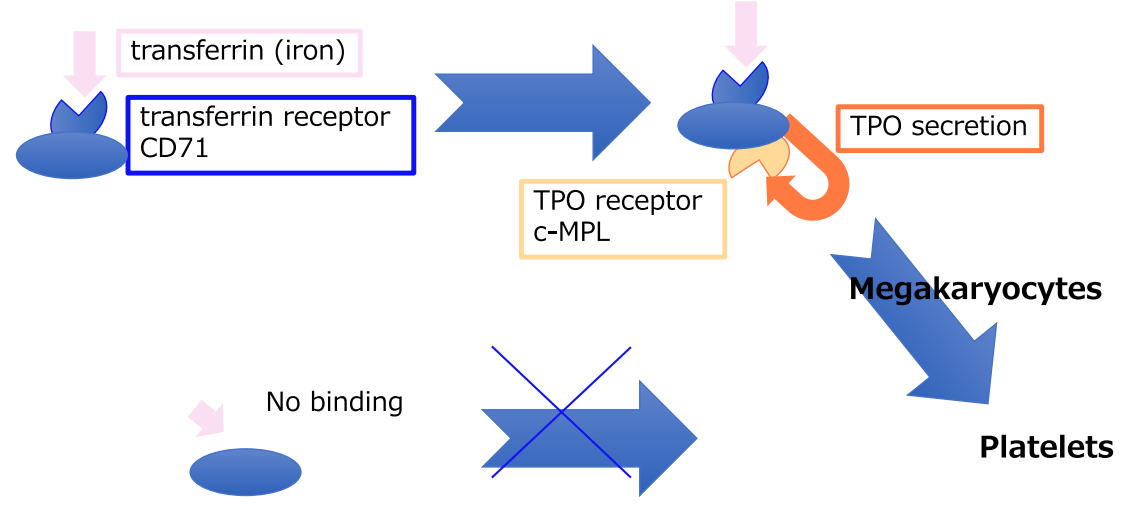

図 1 Selected cells among mesenchymal stem/stromal cells differentiate platelets using endogenous TPO Binding of transferrin, iron transporter, to its receptor CD71 leads to the production of endogenous TPO. Interaction between TPO and its receptor c-MPL is involved in megakaryocyte differentiation and subsequently platelet production.

\section{7. 脂肪由来間葉系幹細胞株 ASCL の樹立, ASCL からの血小板の医療応用}

ここまでの研究成果により, 間葉系幹細胞/間質細 胞は（1）遺伝子導入の必要なし,（2）組換え TPO 添加不要で安定に血小板に分化できる。これは培養 で得られた血小板の医療応用に向けた細胞ソースと して優位性があると考えた.しかし 1 点の改善がの ぞましいと考えた. 現在多くの分野で医療応用目的 に開発されている間葉系幹細胞を含む間質細胞であ るが, この細胞は増殖能の高いが種々の細胞が混在 している. 血小板分化を行なった際の最終産物が再 生医療等製品として再現性よく均一で得るためには 細胞ソースの均一性が必要と考えた. そこで比較的 均一で, 血小板分化に適している adipogenic な細胞 を安定的に得るために, 間葉系幹細胞の精製・株化 技術を開発した ${ }^{13)}$. 脂肪組織由来間葉系幹細胞の中 でも大きな脂肪滴を持つ細胞のみが強い浮力を持つ ことを利用し, 遠心分離後に浮遊した細胞のみを培 養液で満たされたフラスコにいれることで, フラス コの天井に浮遊し付着した細胞が脱分化し, ASCL が得られる. 得られた ASCL はより均一な細胞集団, 分化能を有する細胞集団となっており, 複数の細胞 株で安定して 2 ケ月以上の増殖能を示すことがわ かった.また, ASCL は前述の The International Society for Cellular Therapy の提唱する (1)in vitro で接着細胞 として増殖すること, (2)CD73・CD90・CD105 陽性
であり，かつ CD45 - CD34 - CD14 - CD11b・ CD79a・CD19 およびヒト白血球抗原 class II 陰性で あること, (3)骨芽細胞, 脂肪細胞, 軟骨細胞への分 化能を有すること, の 3 要件を満たし, 間葉系幹細 胞の定義を満たすことも確認された（四2). 細胞表 面抗原のさらなる解析では，CD13，CD29，CD44, CD71, CD166 といった間葉系幹細胞に広く発現する マーカーが陽性であり, CD41 や CD42b といった巨 核球 lineage に特徵的なマーカーが陰性であることも 確認された。 その他にASCLの特徴として, 長期間 の拡大培養後の細胞でも染色体異常を認めず安全性 が高いと考えられることも挙げられる ${ }^{13)}$.

ASCL は, 巨核球・血小板分化誘導培地下での培 養で，巨核球に誘導されたことが表面抗原解析， DNA plody, 免疫染色で確認できた。誘導培地下で 巨核球へ分化中の ASCLの遺伝子発現について, qRT-PCR を用いて検討を行ったところ, TPO, p 45NFE2, beta-1 tubulin, VWF, GATA2 などのヒト生体内 での巨核球分化に深く関わる遺伝子の発現が経時的 に増加していた.一方, 巨核球へ分化誘導中の ASCL では, GATA1 が検出されなかった.一般的に, GATA1 はヒト生体内での造血幹細胞からの分化過程におい て, 赤血球系・巨核球への分化を決定づける重要な 遺伝子の一つとされ, 一方 GATA2 は GATA1 久損・ GATA1 変異マウスにおける巨核球への分化に際して 発現が増加することが知られている。このことから も, ASCL からの巨核球分化は, 通常の造血幹細胞 
A

Obtaining mature adipocytes
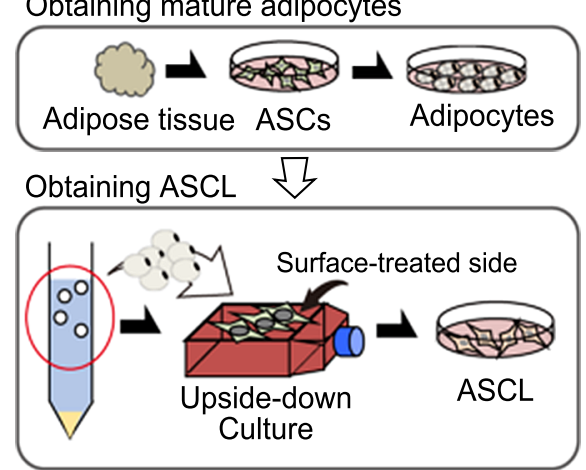

Expansion of $A S C L \sqrt{ }$

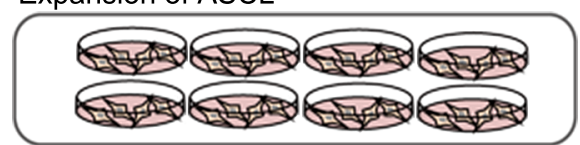

B

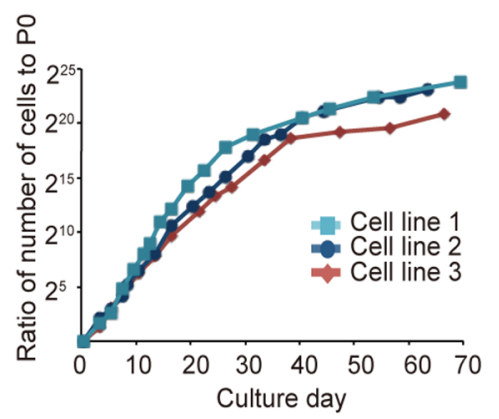

C

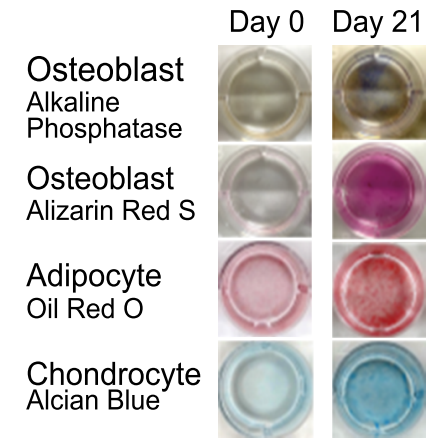

D
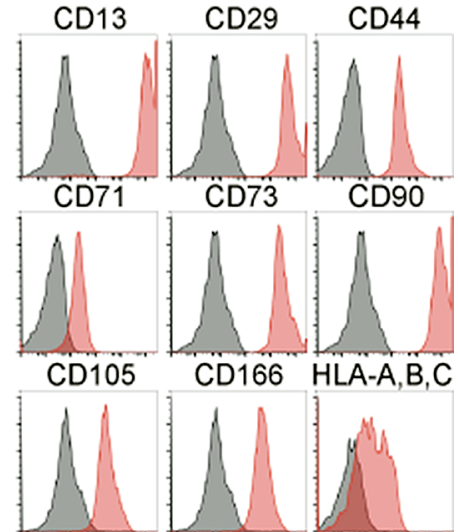

CD11b

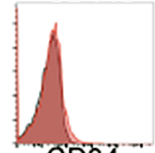

CD34
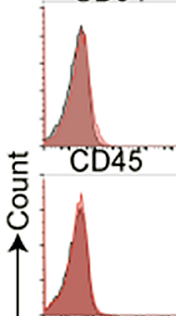

CD56 CD41 CD426

\section{E}

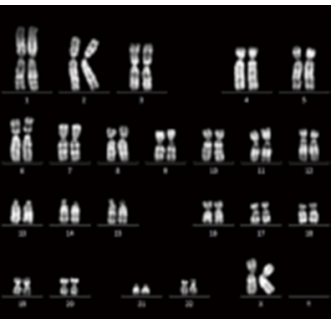

図 2 Characterization of novel human $\mathrm{ASCL}^{13)}$

(A) Schema shows the process to establish ASCL from human subcutaneous adipose tissue. Adipose tissue (0.5-1 g) digested with collagenase was centrifuged to obtain ASCs. ASCs were cultured in conditioned media to differentiate into mature adipocytes. Fatdrop from trypsinized cells were moved to an upside-down culture. Floating mature adipocytes with fat droplets are collected and placed into the flask which is completely filled with the media. ASCL was obtained in upside of culture flask completely filled with medium for 14 days without medium change. A morphological change of fat-drop into adherence cells indicates that ASCL is obtained. (B) Proliferation assay was performed on ASCL established from three different subjects. (C) ASCL differentiated into osteoblasts, mature adipocytes, and chondrocytes. ASCL was cultured in conditioned media for each differentiation, and we assessed the capacity for their differentiations using cell staining. (D) Expressions of surface markers in ASCL were estimated by flow cytometry. Gray color shows isotype control, and red color shows specific markers. (E) Representative data of karyotype analysis of ASCL is shown. 


\section{ASCL-PLT}

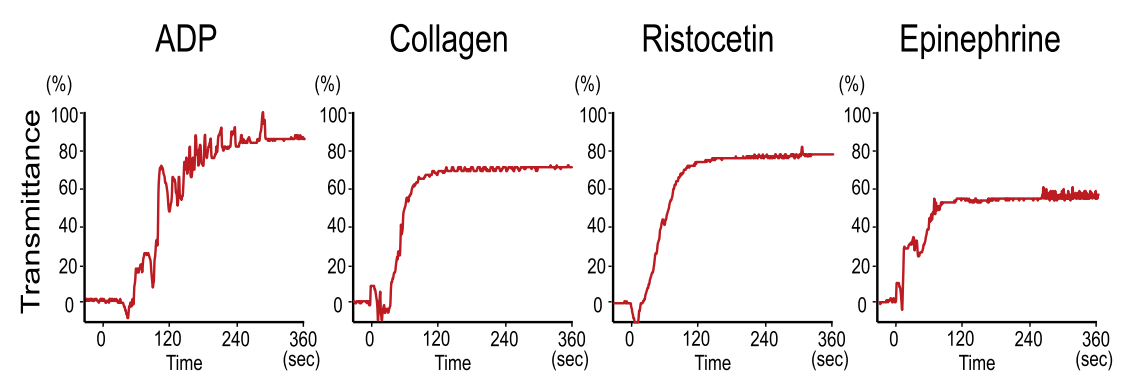

Platelet concentrates

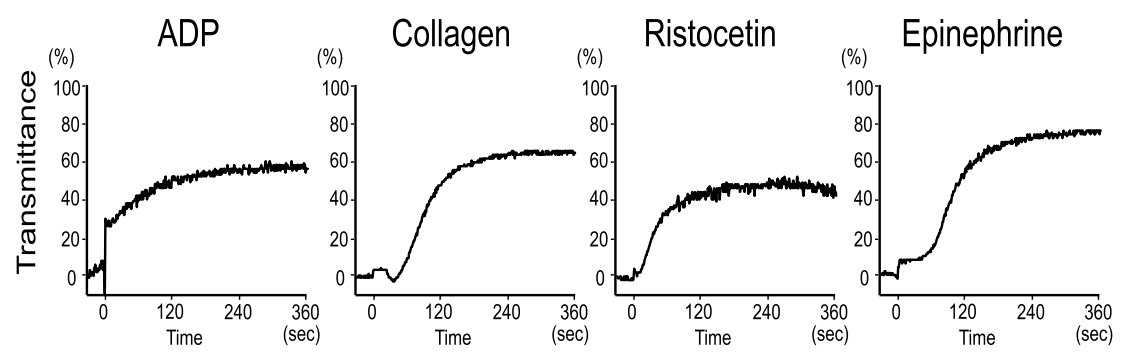

図 3 Functional assay for ASCL-PLT and platelet concentrates ${ }^{13)}$

Agonist-induced aggregation of ASCL-PLT and platelet concentrates recorded under light transmission aggregometry. ADP (20 $\mu \mathrm{M})$, collagen $(5 \mu \mathrm{g} / \mathrm{mL})$, ristocetin $(1.2 \mathrm{mg} / \mathrm{mL})$, and epinephrine $(10 \mu \mathrm{M})$ were used as agonists.

からの巨核球分化と異なるパターンの遺伝子発現が 起きていると推察され, 誘導される巨核球の性質自 体も, 造血幹細胞から分化した巨核球と同一ではな い可能性が考えられた. ASCL 由来の巨核球と CD34 陽性の臍带血細胞から誘導した巨核球について，マ イクロアレイ解析で広く遺伝子発現を比較したとこ ろ, ASCL 由来の巨核球は Cd44, Eng, Nt5e, Thyl （CD90）などの間葉系幹細胞に関連した遺伝子の発 現が多いことがわかった。 マイクロアレイの遺伝子 オントロジー解析や GSEA (Gene Set Enrichment Analysis）でも, ASCL 由来巨核球で細胞接着や間葉 系幹細胞に関連したマーカーの発現が充進している ことが示された。これらのデータから，ASCL由来 の巨核球は, 造血幹細胞由来の巨核球と同様の性質 に加え, 間葉系幹細胞のような特徵も併せ持つこと が示唆された ${ }^{13)}$.

ASCL からの血小板を得るために $10 \mathrm{~L}$ の培地が入 る大きなバイオリアクターに ASCLを入れ培養を 行った. Day12の時点で培地中には, 無核の CD42b 陰性小型細胞が誘導されており，またそれらの細胞 は免疫染色でVWF, beta-1 tubulin, PF4, セロトニ ンを発現しており，血小板が得られたことが確認さ
れた. ASCL 由来の血小板は, CD10, CD13，CD44， CD73, CD90, CD107b といった表面抗原が高発現し ており,うち CD73 と CD90 は前述の The International Society for Cellular Therapy の提唱した間葉系幹細胞 の定義において必須な表面抗原であった。CD90は 細胞接着において重要な役割を持つことが知られて おり, CD42b 陽性の ASCL 由来血小板では，95\%以 上の細胞が CD90を発現していた. ASCL 由来血小 板の機能検討は, 輸血用血小板製剤との比較試験を 行った。実臨床でも使われる比濁法を利用した凝集 計での凝集能測定試験では, どちらの血小板も $\mathrm{ADP}$, コラーゲン, リストセチン, エピネフリンと いった刺激剤に反応し凝集能を示した（図 3)。ま た，放射線照射により血小板減少を起こした免疫抑 制マウスにそれぞれの血小板を投与し，時間をおい てマウスから採血した血液の血小板凝集能について $\mathrm{T}^{-} \mathrm{TAS}^{\circledR}$ (可視的流血下血栓形成解析装置, 藤森工業 社製）を用いて評価したところ，どちらの血小板も 同様に凝集が起きることが確認された。これら研究 結果 ${ }^{13)}$ は, ASCL 血小板の輸血医療への応用への有 用性が示唆された。 


\section{8. おわりに}

脂肪組織由来間葉系幹細胞/間質細胞，骨髄由来間 葉系幹細胞/間質細胞から巨核球・血小板分化を認め たことを端緒にこの現象のメカニズムの解明，医療 応用に向けて脂肪由来間葉系幹細胞株 ASCL の樹 立, バイオリアクターを用いた ASCL からの巨核球・ 血小板産生について概説した. ASCL 血小板の再生 医療等製品としての医療応用は輸血，組織修復など 幅広い用途が期待できる。輸血に先立って，現在は ASCL 血小板の組織修復への適応を目指し，臨床研 究に向けた対応を進めている。

脂肪からの血小板産生をはじめに認めた時から現 在に至るまで, 研究室の皆様からのご教示頂きなが らの議論, 日本血栓止血学会で発表・多くの先生方 との議論機会を頂きました。それら積み重ねが再生 医療等製品の開発につながり，深謝しております。 今後も開発進渉をご報告できるように努力を続けた く研究にのぞみます。

著者の利益相反 $(\mathrm{COI})$ の開示 : 役員・顧問職・社員など（株式会社 AdipoSeeds）, エクイティ（株など）（株式会社 AdipoSeeds），研究 費（受託研究，共同研究，寄付金など）（日水製薬株 式会社，藤森工業株式会社，株式会社 AdipoSeeds, 東ソー株式会社)

\section{文献}

1) Avanzi MP, Mitchell WB: Ex vivo production of platelets from stem cells. Br J Haematol 165: 237-247, 2014.

2) Moreau T, Evans AL, Vasquez L, Tijssen MR, Yan Y, Trotter MW, Howard D, Colzani M, Arumugam M, Wu WH, Dalby A, Lampela R, Bouet G, Hobbs CM, Pask DC, Payne H, Ponomaryov T, Brill A, Soranzo N, Ouwehand WH, Pedersen RA, Ghevaert C: Large-scale production of megakaryocytes from human pluripotent stem cells by chemically defined forward programming. Nat Commun 7: 11208, 2016.
3) Ito $\mathrm{Y}$, Nakamura $\mathrm{S}$, Sugimoto $\mathrm{N}$, Shigemori T, Kato $\mathrm{Y}$, Ohno M, Sakuma S, Ito K, Kumon H, Hirose H, Okamoto H, Nogawa M, Iwasaki M, Kihara S, Fujio K, Matsumoto T, Higashi N, Hashimoto K, Sawaguchi A, Harimoto KI, Nakagawa M, Yamamoto T, Handa M, Watanabe N, Nishi E, Arai F, Nishimura S, Eto K: Turbulence activates platelet biogenesis to enable clinical scale ex vivo production. Cell 74: 636-648, 2018.

4) De Becker A, Riet IV: Homing and migration of mesenchymal stromal cells: How to improve the efficacy of cell therapy? World J Stem Cells 8: 73-87, 2016.

5) Maria AT, Maumus M, Le Quellec A, Jorgensen C, Noël D, Guilpain P: Adipose-derived mesenchymal stem cells in autoimmune disorders: State of the art and perspectives for systemic sclerosis. Clin Rev Allergy Immunol 52: 234-259, 2017.

6) Kirana S, Stratmann B, Prante C, Prohaska W, Koerperich H, Lammers D, Gastens MH, Quast T, Negrean M, Stirban OA, Nandrean SG, Götting C, Minartz P, Kleesiek K, Tschoepe D: Autologous stem cell therapy in the treatment of limb ischaemia induced chronic tissue ulcers of diabetic foot patients. Int J Clin Pract 66: 384-393, 2012.

7) 戸澤圭一, 小野-宇留賀由佳子, 松原由美子: 脂肪組織由 来間葉系幹細胞加の血小板産生. 血液内科 79: 763-757, 2019.

8) Matsubara Y, Ono Y, Suzuki H, Arai F, Suda T, Murata M, Ikeda Y: OP9 bone marrow stroma cells differentiate into megakaryocytes and platelets. PLoS One 8: e58123, 2013.

9) Matsubara Y, Saito E, Suzuki H, Watanabe N, Murata M, Ikeda Y: Generation of megakaryocytes and platelets from human subcutaneous adipose tissues. Biochem Biophys Res Commun 378: 716-720, 2009.

10) Matsubara Y, Suzuki H, Ikeda Y, Murata M: Generation of megakaryocytes and platelets from preadipocyte cell line 3T3L1, but not the parent cell line 3T3, in vitro. Biochem Biophys Res Commun 402: 796-800, 2010.

11) Ono Y, Wang Y, Suzuki H, Okamoto S, Ikeda Y, Murata M, Poncz M, Matsubara Y: Induction of functional platelets from mouse and human fibroblasts by p45NF-E2/Maf. Blood 120: 3812-3821, 2012.

12) Ono-Uruga $Y$, Tozawa $K$, Horiuchi $T$, Murata $M$, Okamoto $S$, Ikeda Y, Suda T, Matsubara Y: Human adipose tissue-derived stromal cells can differentiate into megakaryocytes and platelets by secreting endogenous thrombopoietin. J Thromb Haemost 14: 1285-1297, 2016.

13) Tozawa K, Ono-Uruga Y, Yazawa M, MoriT, Murata M, Okamoto S, Ikeda Y, Matsubara Y: Megakaryocytes and platelets from novel human adipose-derived mesenchymal stem cell line. Blood 133: 633-643, 2019. 